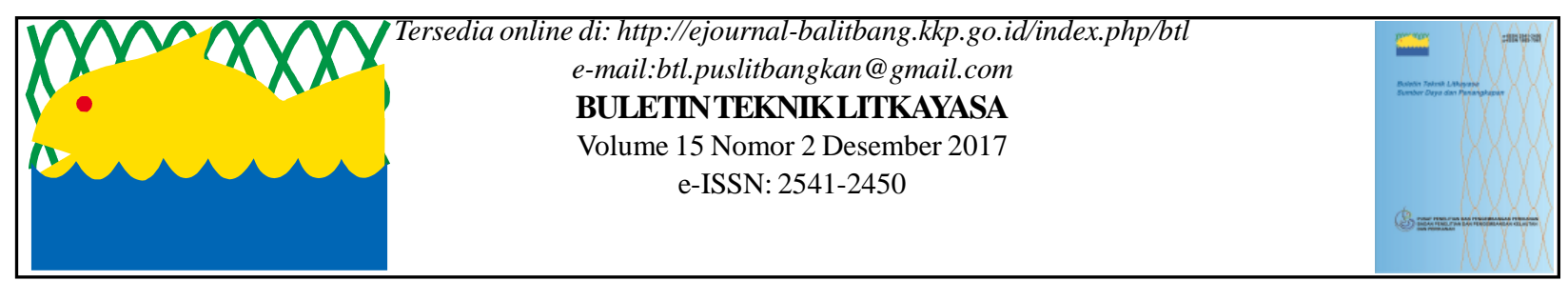

\title{
KEANEKARAGAMAN JENIS DAN KELIMPAHAN FITOPLANKTON DI MUARA BAKAMBAT PERAIRAN ESTUARI DAS BARITO KALIMANTAN SELATAN
}

\author{
Muhtarul Abidin dan Akhlis Bintoro \\ Tekhnisi Balai Riset Perikanan Perairan Umum dan Penyuluhan Perikanan \\ Teregistrasi I tanggal: 30 November 2017; Diterima setelah perbaikan tanggal: 08 Desember 2017; \\ Disetujui terbit tanggal: 13 Desember 2017
}

\section{PENDAHULUAN}

Estuari DAS Barito merupakan muara sungai Barito yang mengalir dari Provinsi Kalimantan Tengah dan bermuara di Laut Jawa pada Provinsi Kalimantan Selatan. Estuari ini terletak pada wilayah administratif Kabupaten Barito Kuala, Provinsi Kalimantan Selatan. Wilayah estuari merupakan perairan yang subur karena kaya akan nutrient yang menyebabkan melimpahnya fitoplankton (Hutabarat, 2001). Fitoplankton merupakan produsen primer dari mata rantai makan dalam suatu perairan (Dawes, 1981). Kondisi dari komunitas fitoplankton dapat mengindikasikan kesuburan suatu perairan (Yuliana \& Tamrin, 2006). Menurut Kingsford et al. (2002) distribusi dan kelimpahan plankton (termasuk fitoplankton) dipengaruhi oleh pasang surut air, salinitas, temperatur, kandungan bahan kimia, dan tekanan hydrostatic.

Fitoplankton mempunyai fungsi penting di perairan karena bersifat autotrofik (menghasilkan sendiri bahan organik makanannya), dapat menyerap energi matahari menjadi oksigen dan menjadi sumber energi biota air yang dialirkan melalui rantai makanan sehingga fitoplankton sering disebut sebagai produsen primer.

Penelitian ini bertujuan untuk mengidentifikasi keanekaragaman jenis dan kelimpahan fitoplankton di Muara Bakambat, DAS Barito Kabupaten Barito Kuala, Provinsi Kalimantan Selatan.

\section{POKOK BAHASAN \\ Lokasi dan Waktu}

Pengambilan sampel fitoplankton dilakukan di muara Sungai Bakambat, DAS Barito, Kabupaten Barito Kuala, Provinsi Kalimantan Selatan pada bulan Maret, Mei, Agustus dan Oktober 2016 (Gambar 1). Posisi geografi daerah penelitian adalah $03^{\circ} 30^{\prime} 624^{\prime \prime} \mathrm{S}$ dan $114^{\circ} 29^{\prime} 795^{\prime \prime}$ E dengan kedalaman perairan $5,5 \mathrm{~m}$.

\section{Alat dan Bahan}

Alat dan bahan yang digunakan untuk pengambilan contoh plankton di lapangan dan analisa sampel di laboratorium dapat disajikan pada Tabel 1.

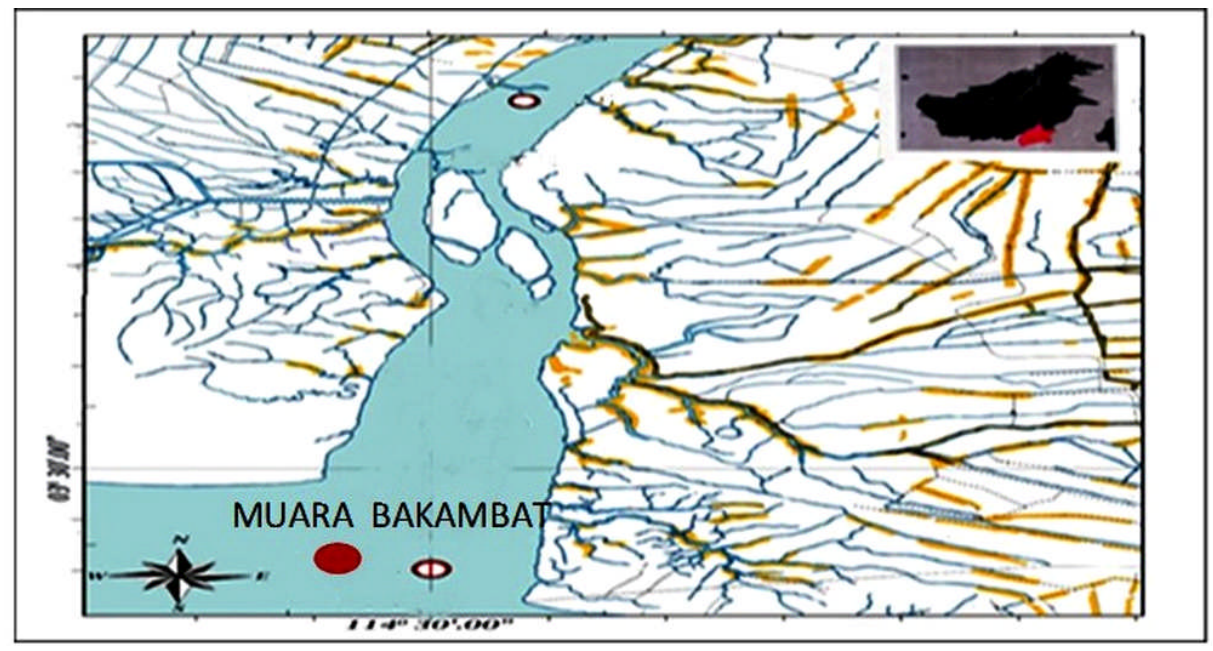

Gambar 1. Lokasi Pengamatan.

Korespondensi penulis:

Jalan Gubernur H.A Bastari No.08, Jakabaring - Palembang

Sumatera Selatan, 30125 
Tabel 1. Alat dan bahan penelitian

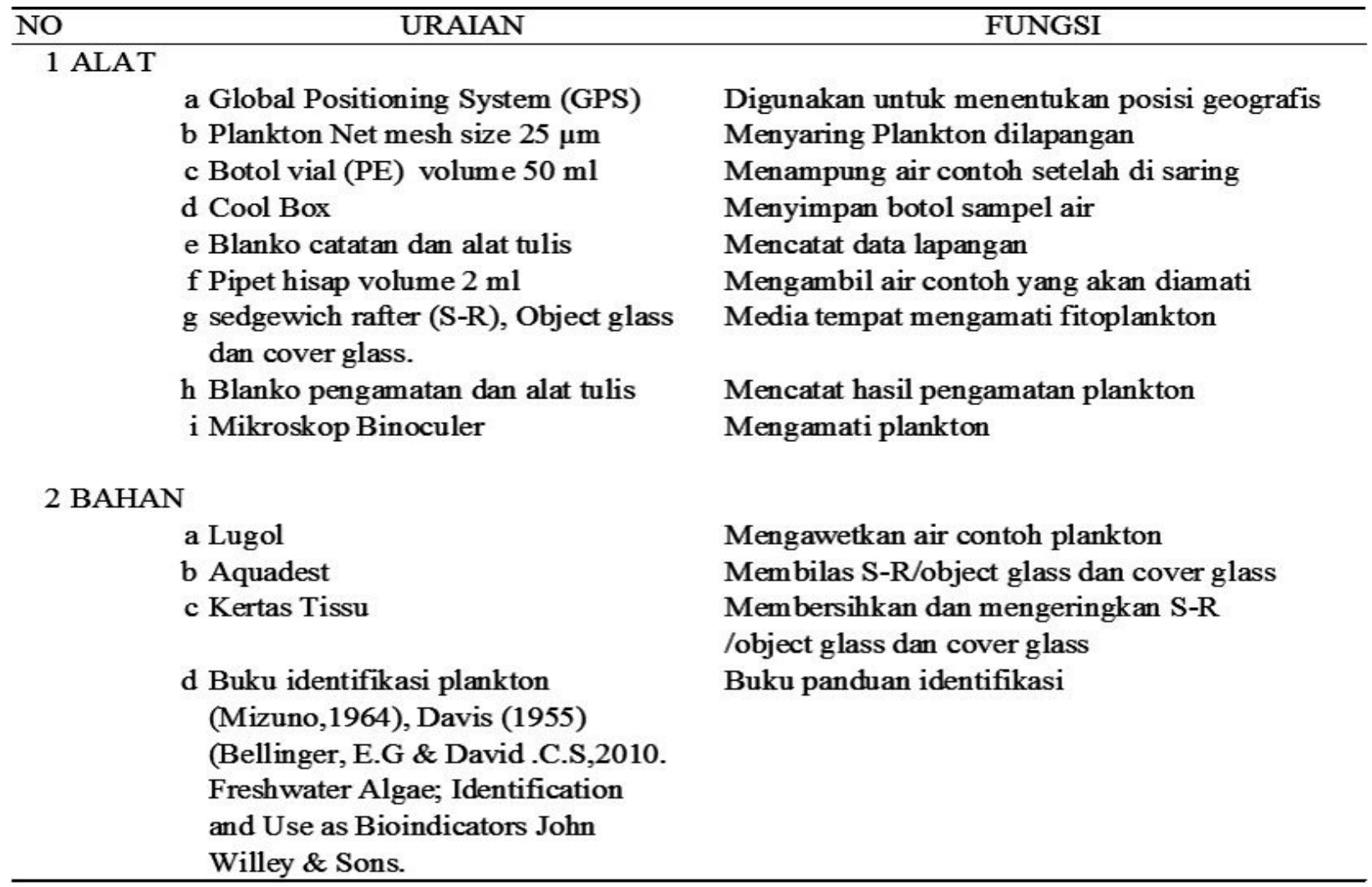

\section{Teknik Pengambilan Sampel Fitoplankton}

Pengambilan sampel dilakukan dengan cara menyaring air contoh sebanyak 50 liter dengan jaring plankton ukuran mata jaring sebesar $60 \mu$. Selanjutnya fitoplankton yang sudah tersaring didalam tabung (Bucket) dituangkan kedalam botol sampel (50-100 $\mathrm{ml}$ ) dan diberi bahan pengawet lugol sebanyak 6 tetes. Botol sampel diberi label atau kode berisi keterangan lokasi stasiun dan tanggal pengambilan sampel (Gambar 2).

Selanjutnya sampel dimasukkan kedalam kantong plastik lalu diikat pakai karet gelang, tujuannya supaya tutup botol tidak terbuka atau botol pecah, yang menyebabkan air sampel tumpah dan terbuang. Sampel dikemas dan disusun dimasukan kedalam cool box, selanjutnya sampel dibawa ke laboratorium.

\section{Analisa Sampel}

Pengamatan sampel dilakukan di laboratotium hydrobiologi dengan terlebih dahulu menyiapkan alat dan bahan seperti: Mikroskop binokuler beserta perlengkapannya, Sadgwik Rafter(S-R), cover glass, pipet hisap, blanko hasil pengamatan dan alat tulis, kertas tissue dan aquadest untuk membilas, buku panduan identifikasi (Gambar 3).
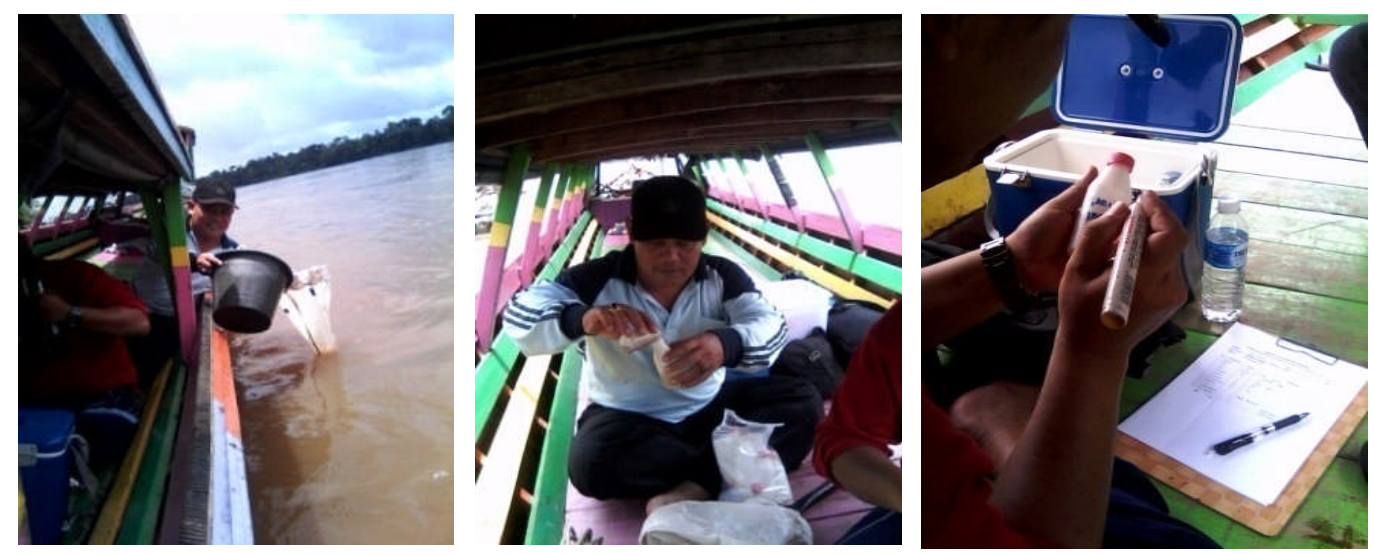

Gambar 2. Pengambilan sampel air dilapangan. 

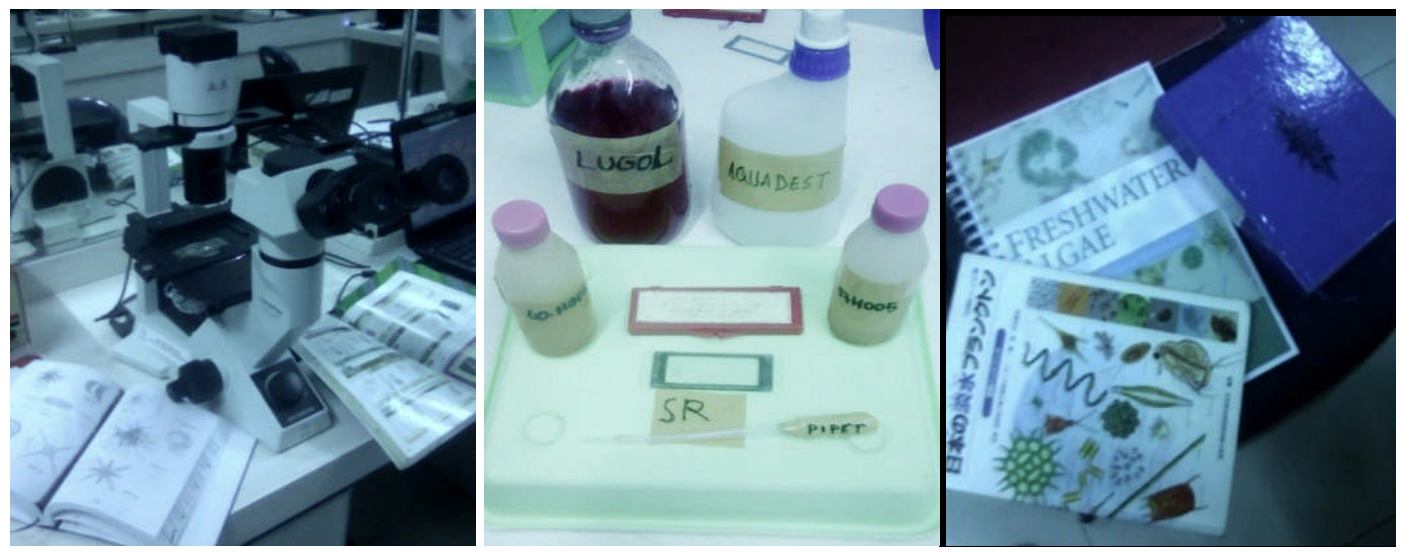

Gambar 3. Peralatan dan bahan pengamatan di Laboratorium.

Pekerjaan selanjutnya setelah semua siap maka sampel plankton dalam botol yang akan diamati di kocok terlebih dahulu tujuannya supaya homogen atau Merata, sampel plankton diambil dengan menggunakan pipet dan dituangkan kedalam S- $R$ sebanyak $1 \mathrm{ml}$ dan ditutup dengan cover glass supaya sampel tidak tumpah (Gambar 4).
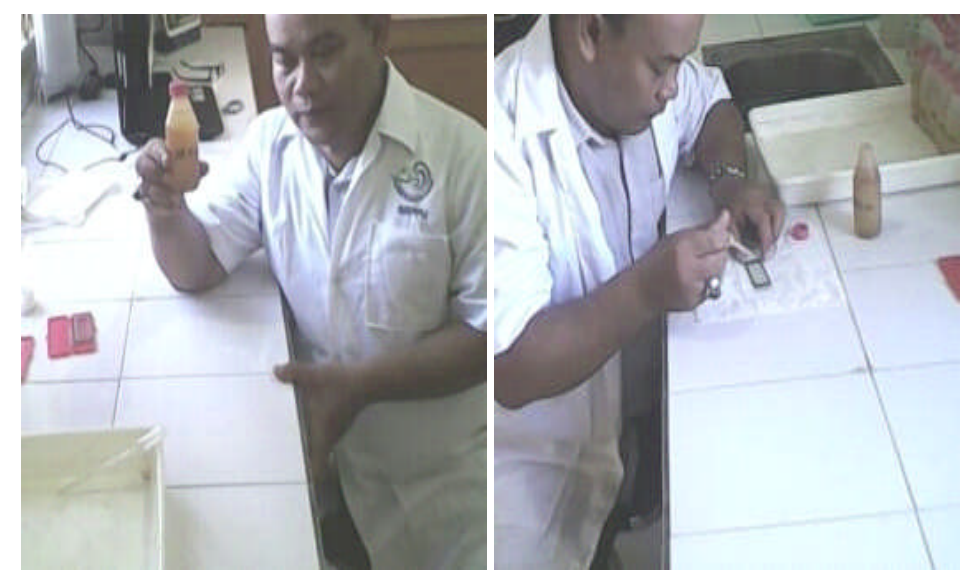

Gambar 4. Proses Awal Pengamatan Plankton.

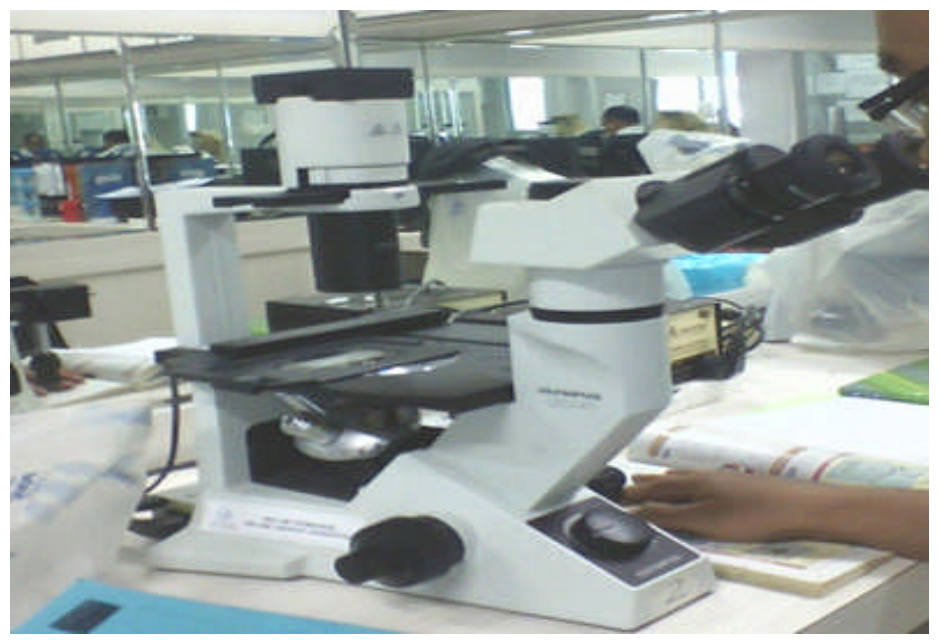

Gambar 5. Proses pengamatan dan identifikasi plankton di laboratorium.
Kemudian diamati dibawah mikroskop dengan pembesaran 10x,20x dan 40x, disesuaikan untuk memperjelas ketika identifikasi, sel fhytoplankton yang terlihat di mikroskop diidentifikasi merujuk pada buku identifikasi C. Davis (1955), Bellinger, E.G \& David .C.S (2010) dan Mizuno (1979) (Gambar $5)$. 


\section{Perhitungan Kelimpahan Fitoplankton}

Kelimpahan jenis fitoplankton dihitung berdasarkan persamaan menurut APHA (2005), sebagai berikut:

$$
N=n \times \mathrm{Vr} / \mathrm{Vo}_{\mathrm{o}} \times 1 / \mathrm{Vs} \mathrm{x} 0 \mathrm{i} / 0 \mathrm{p}
$$

Dengan:

$$
\begin{aligned}
& \mathrm{N}=\text { Jumlah sel per liter } \\
& \mathrm{n}=\text { Jumlah rataan total individu per lapang } \\
& \mathrm{Vr}=\text { Vondang } \\
& \mathrm{Vo}=\text { Volume air tersaring }(\mathrm{ml}) \\
& \mathrm{Vs}=\text { Volume air yang diamati }(\mathrm{ml}) \\
& \mathrm{Oi}=\text { Luas gelas penutup preparat }\left(\mathrm{mm}^{2}\right) \\
& \mathrm{Op}=\text { Luas satu lapang pandang }\left(\mathrm{mm}^{2}\right)
\end{aligned}
$$

\section{HASIL DAN PEMBAHASAN Keanekaragaman Jenis}

Hasil identifikasi menunjukkan bahwa fitoplankton yang ditemukan selama bulan pengamatan di Muara Bakambat perairan Estuari DAS Barito terdiri dari 34 genus yang tergolong dalam empat kelas utama, yaitu Bacillariophyceae, Chlorophyceae, Cyanophyceae dan Xanthophyceae. Kehadiran jenis fitoplankton didominasi oleh kelas Bacillariophyceae yaitu sebanyak 19 genus, kemudian berturut-turut 10 genus, 4 genus dan 1 genera untuk kelas Chlorophyceae, Cyanophyceae dan Xanthophyceae (Tabel 1). Kehadiran jumlah dan keanekaragan jenis juga terlihat bervariasi antara bulan pengamatan. Jumlah jenis dari kelas Bacillariophyceae relative lebih tinggi pada bulan Mei dan rendah pada bulan Maret, demikian juga untuk kehadiran kelas fitoplankton lainnya. Kondisi ini menunjukkan bahwa adanya suksesi bulanan fitoplankton di suatu perairan.

Komposisi kehadiran fitoplankton di Muara Bakambat selama bulan pengamatan yaitu Maret, Mei, Agustus dan Oktober adalah di dominasi oleh kelas Bacillariophyceae $60 \%$, Chlorophyceae $29 \%$, Cyanophyceae $7 \%$ dan Xanthophyceae $4 \%$ (Gambar $6)$.

\section{Kelimpahan Fitoplankton}

Kelimpahan fitoplankton terlihat bervariasi kehadirannya pada setiap bulan pengamatan (Gambar 7). Pada pengamatan bulan Maret kelimpahan tertinggi dimiliki kelompok Chlorophyceae sebanyak $585.4 \mathrm{sel} /$ liter, Cyanophyceae 190.2 sel/liter, Bacillariophyceae $57.8 \mathrm{sel} /$ liter dan Xanthophyceae $28 \mathrm{sel} /$ liter. Pada pengamatan bulan Mei yang banyak diketemukan masih kelompok Chlorophyceae sebanyak $330.4 \mathrm{sel} /$ liter, Bacillariophyceae 223.1 sel/liter, Cyanophyceae 210 sel/liter, dan kelompok Xanthophyceae tidak hadir. Pada pengamatan bulan Agustus dan Oktober kelompok kelas yang banyak diketemukan adalah Bacillariophyceae, kemudian berturut-turut Xanthophyceae, Chlorophyceae dan kelompok Cyanophyceae tidak hadir.

Tabel 2. Jumlah genera yang ditemukan di Muara Bakambat

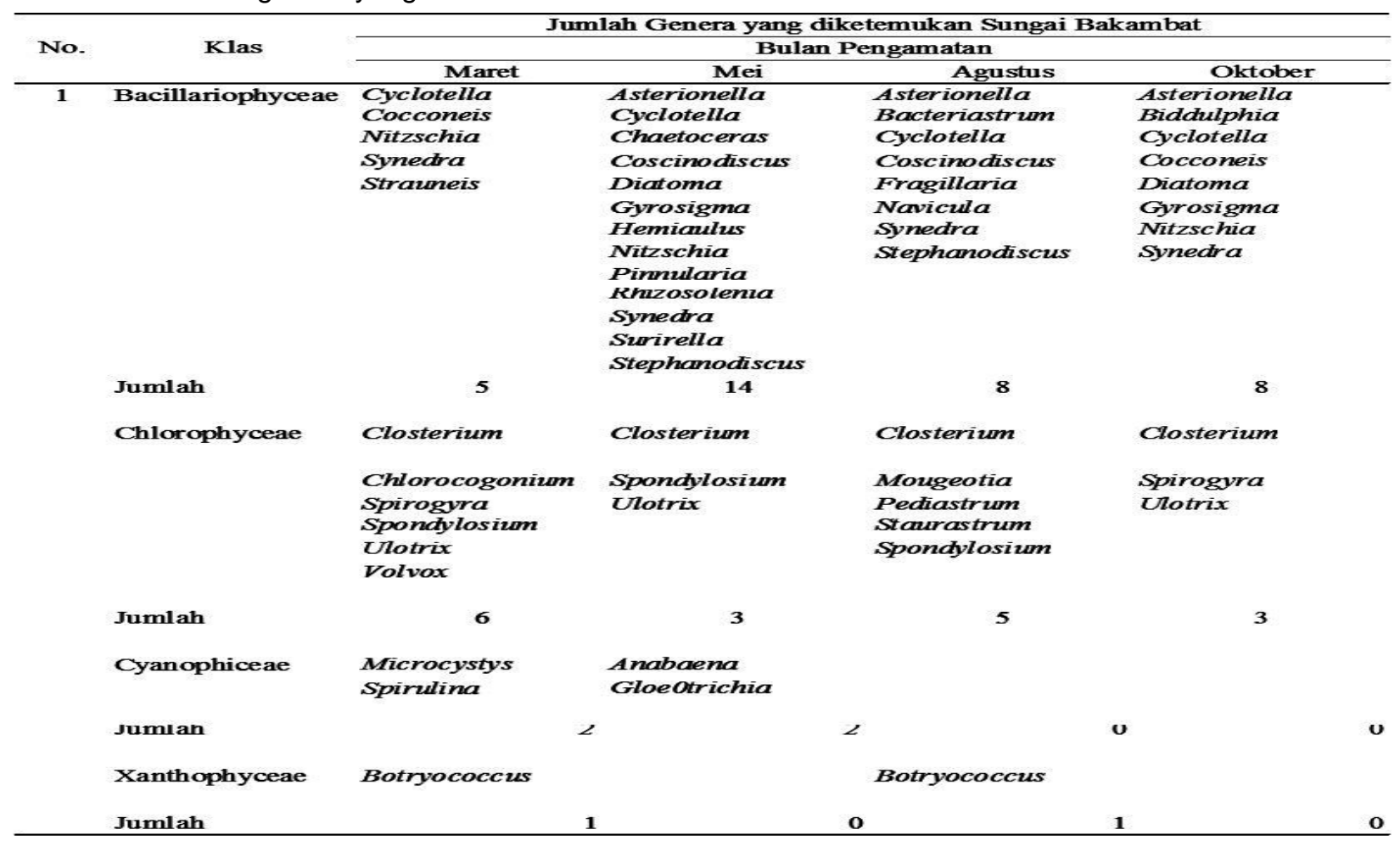




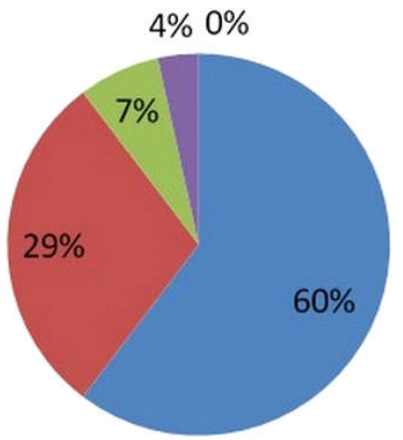

Gambar 6. Komposisi fitoplankton di Muara Bakambat.

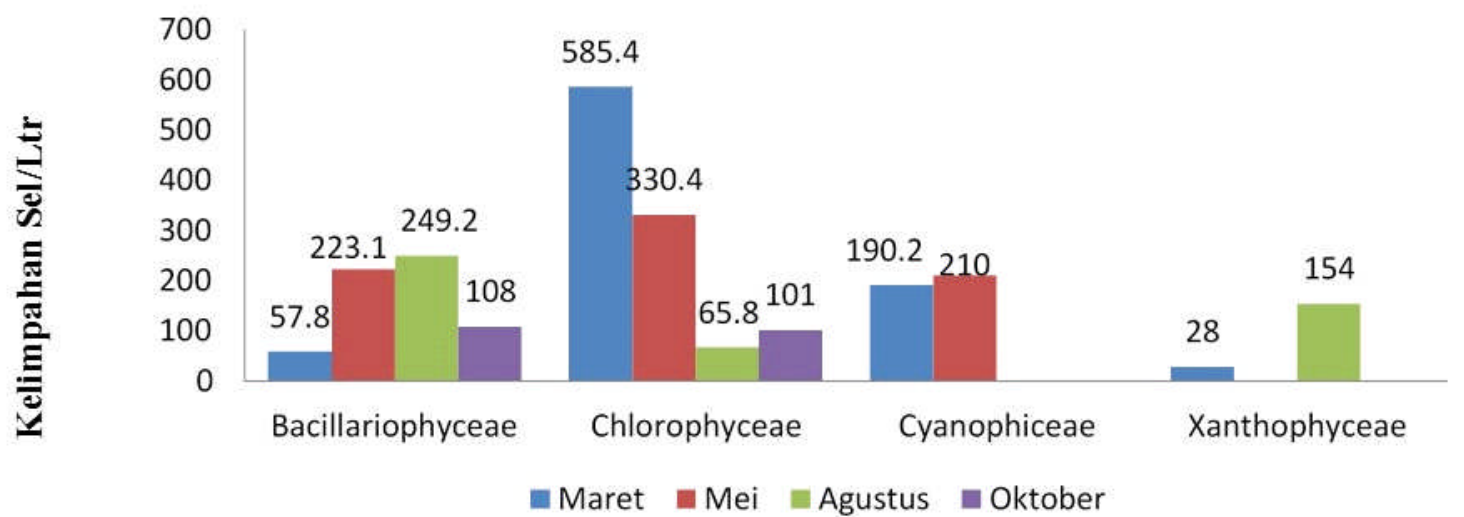

Gambar 7. Kelimpahan fitoplankton di Muara Bakambat

Hasil pengamatan kelimpahan menunjukkan tertinggi terjadi dibulan Maret - Mei dan terendah terjadi di bulan Agustus dan Oktober. Pada bulan Maret didapatkan nilai kelimpahan yang tinggi dan hadie semua kelompok dari fitoplankton. Bulan Maret adalah musim kemarau dimana menyebabkan pengurangan debit air dan terjadinya pemekatan. Bulan Mei, Agustus dan Oktober sudah mulai terjadi musim hujan, yang dapat memberikan sifat pengenceran pada perairan. Nilai yang kelimpahan yang tinggi dapat disebabkan pada area ini selain lokasi penduduk juga terdapat wilayah pertanian masyarakat (sawah pasang-surut) yang memberikan kontribusi phospat yang besar (Rais \& Abidin, 2013).

\section{KESIMPULAN}

Komposisi fitoplankton yang ditemukan selama bulan pengamatan ( Maret, Mei, Agustus dan Oktober) di Muara Bakambat perairan Estuari DAS Barito terdiri dari 34 Genera yang tergolong dalam empat kelas utama, yaitu Bacillariophyceae (19 Genera), Chlorophyceae (10 Genera), Chyanophyceae (4 Genera), dan Xanthophyceae (1 Genera).

Kelimpahan tertinggi terjadi dibulan Maret - Mei dan terendah terjadi di bulan Agustus dan Oktober.
Pada bulan Maret didapatkan nilai kelimpahan yang tinggi hampir pada setiap kelompok fitoplankton, terutama kelompok Chlorophyceae dan Bacillariophyceae

\section{PERSANTUNAN}

Tulisan ini merupakan bagian dari kegiatan Riset Kajian Stok dan Struktur Komunitas Sumber Daya Ikan Perairan Estuari Sungai Barito Kalimantan Selatan, Tahun Anggaran 2014, di BP3U Palembang. Saya sampaikan terimakasih kepada bapak Rupawan.SE, selaku penanggung jawab kegiatan dan anggota team Emmy Dhariyati SE. M.Si, Drs.Asyari, Aroef Hukmanan Rais S.Si, Muhtarul Abidin, Ramli $\mathrm{S} . \mathrm{Pi}$ (pendamping lapangan) atas bantuannya sehingga tulisan ini dapat diterbitkan.

\section{DAFTAR PUSTAKA}

Dawes, C. J. (1981). Marine botany (p. 682). A Willey Interscience. Publ.

Hutabarat. (2001). Pengaruh kondisi oseanografi terhadap perubahan iklim, produktivitas dan distribusi biota Laut. Pidato Pengukuhan Jabatan Guru Besar Madya dalam IImu Oseanografi. 
Fakultas Perikanan dan IImu Kelautan. Universitas Dipobegoro. Semarang.

Kingsford, M.J., Leis.J.M., \& Shanks, A. (2002). Sensory environments, larva abilities and local self-recruitment. Bull. Mar. Sci. 70. 309-340 p.

Rais, H. R \& Abidin, M. (2013). Kelimpahan dan keanekaragaman phytoplankton di Perairan Estuari Sungai Barito, Provinsi Kalimantan Selatan. Prosidiing seminar nasional Perikanan Indonesia
Hasil Penelitian Perikanan dan Kelautan Tahun 2013. Pusat Penelitian dan Pengabdian Masyarakat Sekolah Tinggi Perikanan, Jakarta Selatan. Hal 44-49. Indonesia. Jakrata. Hal 200.

Yuliana \& Tamrin. (2006). Struktur komunitas dan kelimpahan fitoplankton dalam kaitanya dengan parameter fisika-kimia perairan di danau laguna ternate, Maluku utara. Prosidiing seminar nasional limnology 2006. Pusat limnology Lembaga IImu Penelitian Indonesia. Jakrata. p. 200. 